Oleksii Nalyvaiko

ORCID: 0000-0002-7094-1047

Candidate of Pedagogical Sciences, Associate Professor of the Pedagogy Department, V.N. Karazin Kharkiv National University, Svobody Square 6, 61022, Kharkiv, Ukraine, nalyvaiko@karazin.ua

Olena Kalistova ORCID: 0000-0002-2798-3209

3rd year student of the Faculty of Foreign Languages, V.N. Karazin Kharkiv National University, Svobody Square 6, 61022, Kharkiv, Ukraine, kalistovael@gmail.com

Danylo Poliakov ORCID: 0000-0001-5579-7545

3rd year student of the Faculty of Foreign Languages, V.N. Karazin Kharkiv National University, Svobody Square 6, 61022, Kharkiv, Ukraine, danilopoliakov@gmail.com

\title{
DEACTUALIZATION OF HIGHER EDUCATION ON THE EXAMPLE OF STUDYING FOREIGN LANGUAGES
}

The article analyzes the main reasons for de-actualization of higher education in Ukraine on the example of teaching foreign languages. The authors identified four main reasons for the deactualization of higher education: a difficult socio-economic situation caused by an incompetent organization of the production forces of the Ukrainian economy, low quality of educational services, depopulation of the Ukrainian population and a decrease in the quality of the teaching staff, a permanent increase in the cost of higher education. To confirm our assumptions, we carried out an introduction of students from different parts of Ukraine who study a foreign language. We interviewed six respondents from different universities across Ukraine about the topic: V.N. Karazin Kharkiv National University, Horlivka Institute for Foreign Languages, Ivan Franko National University of Lviv, Kyiv National Linguistic University, National Technical University "Kharkiv Polytechnic Institute" and Ternopil Volodymyr Hnatiuk National Pedagogical University. Every respondent was given a name (A-F) in order to keep their 
anonymity. We have presented the results of the interview. Students say that problems do not always depend on universities, but personal traits of students and teachers and modern tendencies in labor market. We gave some recommendations: the curriculum must be corrected in favor of main subjects or even subjects that will make graduates more appropriate for some posts than people without degree; teaching staff must have special pedagogical degree in order to improve their pedagogical skills; universities need to employ native speakers of taught languages; universities need to elaborate such study programs that will make their graduates more attractive candidates in labor market. The main conclusion must be so: the system of higher education has to keep up with the times and change itself according to labor market, students' beliefs and modern tendencies in science and technology.

Keywords: Deactualization, Foreign Languages; Students, teaching staf;, Ukrainian education system; Universities.

(C) Nalyvaiko Oleksii, Kalistova Olena, Poliakov Danylo, 2021

https://doi.org/10.28925/2312-5829.2021.2.10

Introduction. Global trends in the transformation of social relations, which permeate all the established models of interaction and communication between people, show that the times of change are coming. Long-established patterns of behavior and interaction between people and institutions are no longer as effective as in the last century. The leading force of the XXI century is the digitalization and informatization of social relations, which no longer require personal accessibility of the participants in the same room. To obtain educational information, you no longer need to contact recognized professionals who have higher education. In the modern world, it is not uncommon to become an effective means of non-formal and informal education, which in some areas is not inferior to traditional higher education, for example, IT (IT in Ukraine, 2020; Naumuk, 2015) and foreign languages. Traditional education in this context is becoming an exception, and is the driving force behind these transformational processes in a dialectical sense, but it should be noted that the number of students per thousand people is decreasing over the years, especially in Ukraine. What caused this process and where is Ukrainian higher education heading? An attempt to answer this crucial question can be to determine the main factors that are inherent in this problem.

The first and most important factor in the deactualization of higher education in the eyes of students and society in Ukraine is the decline of the productive forces of the state 
due to the uncontrolled economic policy pursued throughout the years of independence. Confidence in the future, the relevance of your profession and general interdisciplinary knowledge and skills are a significant factor when student choose a higher education institution (HEIs) for training. Unfortunately, the current state of economic and social development of Ukraine is not to the delight of either applicants or their parents, which is exacerbated by the global economic crisis, which has severely "hit" the welfare of Ukrainians. Only the IT sector shows a small but sustainable development, but it cannot satisfy all the needs of our state.

The second factor influencing the deactualization of higher education is the quality of the educational services provided. Let's give an example of obtaining higher education in foreign languages. Quite often, in the library funds of HEIs we can find outdated editions of albeit effective, but irrelevant textbooks and methodological recommendations for the study of foreign languages. We understand that this problem is a consequence of the first factor of deactualization of higher education, without proper funding it is impossible to create high-quality teaching materials and especially to buy them abroad. This problem has been pursuing Ukrainian higher philological education since the nineties of the twentieth century, and its solution is not yet seen as quick. The aforementioned factor of deactualization of higher education is reinforced by the insufficiently high level of training of the teaching staff. Thus, the best graduates, even after working in the field of higher philological education, when faced with meager wages for their labor, choose the private sector of the economy or even leave the territory of Ukraine in search of a better life. This situation significantly reduces the educational and professional potential of training in the specialty 035 - philology.

The third factor in the deactualization of higher education in Ukraine is the depopulation of the nation (Official site of the State Statistics Service of Ukraine. Population, 2020). It was noted above that uncertainty about their future prompts young people to migrate to other countries and regions. A decrease in the number of students in higher education in Ukraine has been observed since the 2009/2010 academic year (Official site of the State Statistics Service of Ukraine, 2020), and this leads to a decrease in rates and a reduction in teachers and, as a rule, not the worst and unprofessional of them 
in our opinion. Observing such situation, applicants and their parents think about choosing an alternative for themselves. Here we can recall a significant number of online and offline schools for the study of foreign languages, which are represented by both Ukrainian and foreign linguists.

And finally, the fourth factor in the deactualization of higher education is the increase of the education cost and the significant time to obtain a full academic higher education (Fig. 1). Modern students, already in their 2nd year, begin to look for a place to work (as we can see, the first factor has a cross-cutting effect), which significantly distracts and creates problems in full-time education. The almost annual increase of the educational services cost creates conditions alternatives. An important factor for modern students is the study time, full-time programs for the preparation of philologists, unfortunately, do not have the flexibility that students need and this can cause conflict situations that can even reach expulsion, therefore non-formal education multiplied by the exponential development of digital technologies and the Internet networking allows students to see a powerful alternative to traditional higher education.

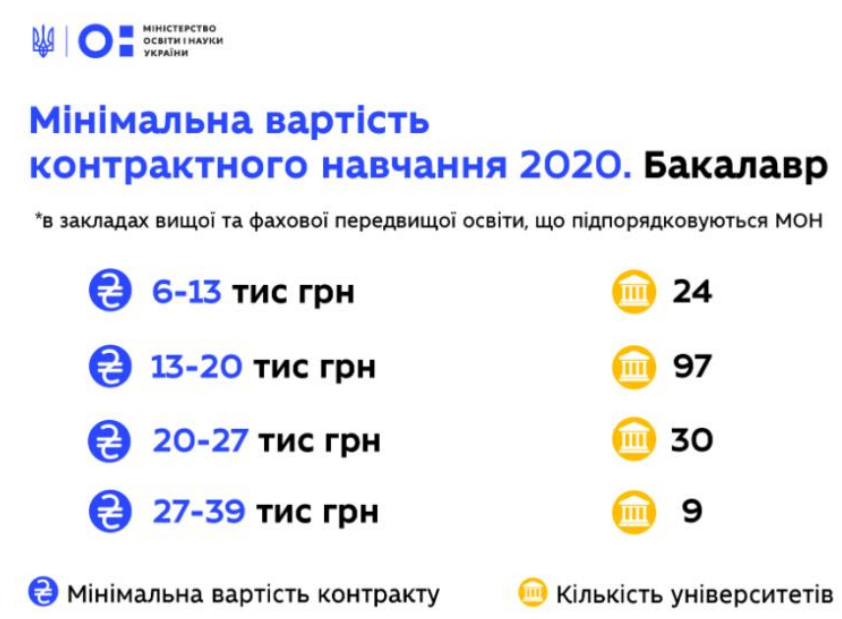

Fig. 1. The minimum cost of contract education in 2020 for bachelors (Official site of the Ministry of Education and Science of Ukraine, 2020.)

The main aim of this article is to understand why degree on Foreign Languages is not seen relevant by students' nowadays.

Method. We interviewed six respondents from different universities across Ukraine about the topic: V. N. Karazin Kharkiv National University, Horlivka Institute for Foreign Languages, Ivan Franko National University of Lviv, Kyiv National Linguistic University, 
National Technical University «Kharkiv Polytechnic Institute» and Ternopil Volodymyr Hnatiuk National Pedagogical University. Every respondent was given a name (A-F) in order to keep their anonymity. We asked students following questions:

1. Why is there a tendency of depreciation of higher education in Ukraine?

2. What problems did you face, studying foreign languages in university?

3. Are all the aspects of a language (grammar, speaking, vocabulary, listening and so on) paid attention or no?

4. Does the level of language proficiency correspond to a year of studying?

5. Do you have any ideas how to improve language studying in university?

We analyzed their responds and tried to give some recommendations.

The main part of the study. The issues of deactualization in education are not considered very often, but this concept is often used in philosophy and cultural studies. The concept of deactualization is an essential element in the context of determining the factors of loss of relevance for students of modern philological education.

According to S. Troitsky concept of "deactualization - deliberate displacement from the actual cultural space beyond the boundaries of official culture, that is, depriving one or another phenomenon of the possibility of broadcasting its "image"' (Troitsky, 2015, p. 71). Also, S. Troitsky indicates that the deactualization process in culture forces the system to readjust in accordance with the existing situation. For such reconfigurations, a small amount of time is required, but it is enough for cultural meanings to be lost. It should be noted that the culture is not restored to its original form, it is impossible to return to the lost form. At the same time, the processes of "deactualization" and "reactualization" should be considered as the driving force of culture (Troitsky \& Gulyaeva, 2017, p. 483). In online dictionaries, the concept of deactualization is considered as: "making less real or existent" (Ludwig, 2021; WordSense Dictionary, 2021).

We gave definition to respondents such definition of "deactualization": as a process of losing the importance of any phenomenon for the subject of perception. In the context of deactualization of higher education, this concept is seen as a process of losing the personal importance of higher education and the search for effective alternatives. 
Interviewing students made it possible to determine the most significant factors of decimalization of higher education. The main problems of higher education in Ukraine, mentioned by the respondents are:

- There are many unnecessary subjects, not related to the specialization;

- Lack of native speakers;

- Unbalanced attention to different aspects of a language;

- Tendency of employing people without degree but that have appropriate skills;

- Pedagogical incompetence of teachers;

- Possibility to learn a foreign language without degree.

Let's consider in more detail the received answers of students.

1) Unnecessary subjects. The respondents tend to think that some subjects are not related to their specialization and area of study. Student B from Horlivka Institute for Foreign Languages: "Some subjects do not have any reference to learning language, for instance, Religion. I still have no clue why we studied it". Student F from Ternopil Volodymyr Hnatiuk National Pedagogical University says that these subjects exhaust students, so that they do not have much time and desire to prepare, for example, homework for their main subjects (foreign languages). They advocate that this system must be changed. Student D from Kyiv National Linguistic University proposes to reduce the period of study removing from the curriculum so called 'minor' subjects. Student $\mathbf{E}$ from National Technical University «Kharkiv Polytechnic Institute» says that they have different unrelated to their degree subjects, for example, Economics in Ukrainian.

2) Lack of native speakers. Every respondent mentioned the problem of shortage of communicating and interacting with native speakers. Student C from Ivan Franko National University of Lviv says that students need to talk to the foreigners in order to get to know their way of speaking, some special features of accents, intonation. Student D from Kyiv National Linguistic University states that "the contact with a native speaker should be involved in studying process because if it is missed, it can lead to the situation when students become confused and puzzled in front of an English or Scottish, for example". Furthermore, he highlights that traditional language must be known by Nalyvaiko Oleksii, Kalistova Olena, Poliakov Danylo, 2021 
graduators but makes one note: "Our teachers should not forget about everyday speaking that we will have to translate also". Student A from V. N. Karazin Kharkiv National University believes that if this aspect of studying of foreign language is absent, it would result in difficulties during the communication process that are caused by linguocultural aspect: "Different society, customs, traditions, mentality and way of thinking can be a stumbling block to understand and then to translate correctly the speech of natives".

3) Unbalanced attention to different aspects of a language. All of the respondents consider that some aspects are not paid attention by the curriculum and/or teachers. Student D from Kyiv National Linguistic University believes that speaking and writing do not have enough attention. Student F from Ternopil Volodymyr Hnatiuk National Pedagogical University supposes that only learning all the aspects a person can master a language. They have faced many times when teachers did not want to pay attention to all the aspects. Student $\mathbf{C}$ from Ivan Franko National University of Lviv told us about their experience: "I had a teacher that ignored phonetics and did it consciously, however, it was just a single case". But they add that they had different classes for every aspect of language. Furthermore, they have a subject that uses all the aspects of a language. Student A from V. N. Karazin Kharkiv National University thinks that there are no appropriate speaking classes, so students are not able to express their thoughts in a foreign language. Additionally, they pay too much attention to grammar. They seldom have classes that improve their writing competence.

4) Tendency of employment without degree. We can see such a process in the whole world and Ukraine is not an exception. Employers are eager to see person that have practical possibilities, both soft and hard skills. Thus, Student F from Ternopil Volodymyr Hnatiuk National Pedagogical University considers that there are lots of highpaid jobs which do not demand degree but skills, competencies and qualifications instead that any person can operate even though they did not graduate from the University. Student E from National Technical University «Kharkiv Polytechnic Institute» pointed to the absence of some particular subjects as IT English or Medical English which she supposes necessary for the acquisition of interpreters' and translators' skills. Student A from V. N. Karazin Kharkiv stated that their studying process could not prepare students 
for their job because of the knowledge control system which was aimed to "kill the personality of the translator and make people who know only active vocabulary". Besides, she complains of the quality and relevance of their manuals as they have a lot of words which are not used now. This means that educational system is focused only on theoretical aspect but not on practical one that makes the process of finding the job more complicated.

5) Pedagogical incompetence. As we see, many teachers are not able to motivate students, furthermore, they do not have an appropriate language level. Student A from V. N. Karazin Kharkiv National University says that some teachers usually do not have enough knowledge on subject they teach. For instance, some of them have strong accent teaching Oral Practice of English or they spend too much time on unrelated topics (discussion in Russian or Ukrainian, their 'life-story' and so on). That, on their mind, does not motivate students to study a subject. Student E from National Technical University «Kharkiv Polytechnic Institute» noted that they have B2 in their year of study, but a teacher gave them a $\mathrm{C} 2$ test that does not correspond to their level and was seen as ' $a$ stupid and even humiliating thing'. Student B from Horlivka Institute for Foreign Languages says: "Problems with teaching staff started when the University moved from Horlivka. Generally, we had problems with studying process". But they add: "Before it, I was satisfied with our classes, we could practice English and all the subjects were in English". Student F from Ternopil Volodymyr Hnatiuk National Pedagogical University advocates that some teachers cannot motivate students and do not like subjects they teach themselves.

6) Learning foreign languages without degree. The respondents have a common opinion that nowadays it is possible to learn foreign language themselves without entering the University and lots of people already know at least English. Student B from Horlivka Institute for Foreign Languages thinks that the main reason why degree on Foreign Languages is not relevant because now there are many courses of foreign languages. "It is better than studying 5 years and then realize that it is not yours" - it is the point of their interview. Student A from V. N. Karazin Kharkiv National University states that "it would be more useful to finish a language course and then get a certificate that guarantees your level of proficiency to the potential employers than have a degree on 
Foreign Languages without any confirmation". Student E from National Technical University «Kharkiv Polytechnic Institute» claims that they have been studying general English and German for four years already and if students want to enhance their knowledge in some special area they have to do it on their own. Also Student $\mathbf{F}$ from Ternopil Volodymyr Hnatiuk National Pedagogical University noted that level of proficiency after four years of studying is not satisfactory. It is motivated by the fact that majority of students start working just after their graduation without appropriate knowledge base.

We must admit that, although, all the reasons of deactulization of higher education in area of Foreign Languages and Linguistics and problems that respondents have faced are similar, Ivan Franko National University of Lviv here stays separately. Student C during interview said many times that they are delighted with the level of teaching, curriculum and so on. This person also advocates the idea of existence of higher education in area of Foreign Languages: "It gives personal development in different areas. Of course, nowadays, you can become whoever you want without degree, but I think that degree is still important". They noted that this degree is still in demand in Ukraine, because we do not have a good education in this area.

Recommendations. Analyzing students' responds we came to conclusion that problem of deactulization of higher education have absolutely different aspects that must be eliminated. Problems do not always depend on universities, but personal traits of students and teachers and modern tendencies in labor market.

To begin with, the curriculum must be corrected in favor of main subjects or even subjects that will make graduates more appropriate for some posts than people without degree. This recommendation leads to another: all the aspects of language learning should be paid attention. It can be done by adding subjects devoted especially to one aspect (for example, classes of Academic English) or adding different aspects to usual foreign language classes. If the curriculum is changed, the more possibilities of language training appear. 
Also, teaching staff must have special pedagogical degree in order to improve their pedagogical skills. We offer to give more seminars, classes and so on for teachers, so that they will have more training and more knowledge on new teaching techniques and ICT.

Also, we recommend universities to employ native speakers of taught languages. It does not mean that they must teach all the subjects, but it may effective for students to learn a 'living' language in interaction with native speakers. Native speakers may better explain local traditions, customs and so called 'national character'.

We recommend universities to elaborate such study programs that will make their graduates more attractive candidates in labor market. For instance, universities can differentiate some subjects in order to teach more about different aspects of a language. Also, universities may encourage some organizations to offer non-paid working practice in the area of translation, so that, students will be able to have a more profound notion about work of a translator/interpreter. This way, students will get training and obtain necessary skills for their future work.

The processes of deactualization of higher education on the example of studying foreign languages allow us to draw a disappointing conclusion that the modern system of providing educational services in Ukraine requires significant changes and shifts, since ignoring the above factors (which are mostly objective in nature and cannot be changed without reconfiguring the modern distribution system social and production benefits towards investment in human capital) can lead to the collapse of the modern model of higher education.

Conclusions. As it was shown, nowadays, degree on Foreign Languages in Ukraine suffers the process of deactualization. Even students do not always see their degree as something vital for their future career. These tendencies are similar in different universities in various parts of Ukraine. On our mind, the students' opinions are exponential. So, we have proposed some ways of solving problems of deactualuzation of higher education in area of Foreign Languages, basing on students' responds. We must understand that the problem is not only about particular universities, but the system of higher education in Ukraine on the whole. We believe that a single university just could not solve the problem of deactualization itself. It is extremely important to elaborate such 
recommendations in cooperation with universities' administrations, students and the Ministry of Education and Science of Ukraine. Although the deactualization is a global tendency, it has particular features in Ukraine. The main conclusion must be so: the system of higher education has to keep up with the times and change itself according to labor market, students' beliefs and modern tendencies in science and technology.

\section{References}

IT in Ukraine: where are we moving? (2020). Electronic resource. Access mode: https://dou.ua/lenta/columns/future-of-it-ukraine/ (ukr.)

Naumuk I. M (2017). Osvitni trendy u pidhotovtsi maibutnikh IT-fakhivtsiv [Educational trends in the training of future IT professionals]. Current issues of modern computer science, 2017, 5, 126-129. (ukr.)

Official site of the State Statistics Service of Ukraine (2020). Zaklady vyshchoi osvity [Institutions of higher education]. Electronic resource. Access mode: http://www.ukrstat.gov.ua/operativ/operativ2005/osv_rik/osv_u/vuz_u.html (ukr.)

Official site of the State Statistics Service of Ukraine (2020). Naselennia [Population]. Electronic resource. Access mode: http://www.ukrstat.gov.ua/operativ/operativ2007/ds/nas_rik/nas_u/nas_rik_u.html (ukr.)

Official site of the Ministry of Education and Science of Ukraine (2020). Minimalna vartist kontraktnoho navchannia 2020: MON opublikuvalo rozrakhunok [Minimum cost of contract training 2020: The Ministry of Education and Science has published the calculation]. Electronic resource. Access mode: https://mon.gov.ua/ua/news/minimalna-vartist-kontraktnogo-navchannya-2020mon-opublikuvalo-rozrahunok (ukr.)

Ludwig (2021). Deactualization. Electronic resource. Access mode: https://ludwig.guru/s/deactualization (eng.)

WordSense Dictionary (2021). Deactualization. Electronic resource. Access mode: https://www.wordsense.eu/deactualizations/ (eng.)

Troitsky S. A. (2015). Problema terminologicheskoy tochnosti pri izuchenii zon kul'turnogo otchuzhdeniya [The problem of terminological accuracy in the study of cultural exclusion zones]. New literary review, 2015, 3(133), 71 (rus.)

Troitsky S. A., Gulyaeva N. L. (2017) Metod kul'turnykh preobrazovaniy Mapping [A Method of Cultural Transformations Mapping]. Observatory of Culture, 14(4), 482-488. DOI: 10.25281/20723156-2017-14-4-482-488. (rus.) 


\section{ДЕАКТУАЛІЗАЩЯ ВИЩОЇ ОСВІТИ НА ПРИКЛАДІ ВИВЧЕННЯ ІНОЗЕМНИХ МОВ}

Олексій Наливайко, кандидат педагогічних наук, доцент кафедри педагогіки, Харківський національний університет імені В. Н. Каразіна, майдан Свободи 6, 61022, Харків, Україна, nalyvaiko@ karazin.ua Олена Калістова, студентка III курсу факультету іноземних мов, Харківський національний університет імені В. Н. Каразіна, майдан Свободи 6, 61022, Харків, Україна, kalistovael@gmail.com

Данило Поляков, студент III курсу факультету іноземних мов, Харківський національний університет імені В. Н. Каразіна, майдан Свободи 6, 61022, Харків, Україна, danilopoliakov@ gmail.com

У статті аналізуються основні причини деактуалізащіі вищої освіти в Украйні на прикладі навчання іноземних мов. Авторами виділені чотири основні причини деактуалізаціі вищої освіти: складна соціально-економічна ситуащія, викликана некомпетентною організаиією виробничих сил української економіки, низька якість освітніх послуг, депопулячія украйнського населення $i$ зменшення якісного викладацького складу, перманентне збільшення вартості вищої освіти. Для підтвердження своїх припущень ми провели інтерв'ювання студентів з різних куточків України, які вивчають іноземну мову. Ми опитали шість респондентів з різних університетів Украйни на ию тему: Харківський національний університет імені В. Н. Каразіна, Горлівський інститут іноземних мов, Львівський національний університет імені Івана Франка, Київський начіональний лінгвістичний університет, Національний технічний університет "Харківський політехнічний інститут» та Тернопільський національний педагогічний університет імені Володимира Гнатюка. Кожному респонденту дали ім'я (A-F), щоб зберегти їх анонімність. Ми представили результати інтерв'ю в цій статті. Студенти кажуть, щзо проблеми не завжди залежать від вишів, а найчастіше від особистих якостей студентів і викладачів або сучасних тенденцій на ринку праці. Ми дали кілька рекомендацій: навчальну програму необхідно скоригувати на користь основних предметів або навіть предметів, які зроблять випускників більш придатними для деяких посад, ніж людей без наукового ступеня; педагогічний склад повинен мати спеціальну педагогічну освіту для підвищення своєї педагогічної майстерності; університети повинні наймати носіїв мов, які викладаються; університетам необхідно розробити такі навчальні програми, які зроблять їх випускників більш привабливими кандидатами на ринку прачі. Головний висновок повинен бути таким: система вищої освіти повинна йти в ногу з часом $i$ змінюватися в залежності від ринку праці, переконань студентів $і$ сучасних тендениій у науиі та технологіях.

Ключові слова: деактуалізація; іноземні мови, студенти; викладачі; украӥнська система освіти; університети. 


\section{ДЕАКТУАЛИЗАЦИЯ ВЫСШЕГО ОБРАЗОВАНИЯ НА ПРИМЕРЕ ИЗУЧЕНИЯ ИНОСТРАННЫХ ЯЗЫКОВ}

Алексей Наливайко, кандидат педагогических наук, доцент кафедры педагогики, Харьковский национальный университет имени В. Н. Каразина, площадь Свободы 6, 61022, Харьков, Украина, nalyvaiko@karazin.ua

Елена Калистова, студентка III курса факультета иностранных языков, Харьковский национальный университет имени В. Н. Каразина, площадь Свободы 6, 61022, Харьков, Украина, kalistovael@gmail.com

Даниил Поляков, студент III курса факультета иностранных языков, Харьковский национальный университет имени В. Н. Каразина, площадь Свободы 6, 61022, Харьков, Украина, danilopoliakov@gmail.com

В статье анализируются основные причины деактуализации выстего образования в Украине на примере обучения иностранным языкам. Авторами выделены четыре основные причины деактуализации высшего образования: сложная сочиально-экономическая ситуация, вызванная некомпетентной организацией производственных сил украинской экономики, низкое качество образовательных услуг, депопуляция украинского населения и уменьшение качественного преподавательского состава, перманентное увеличение стоимости высшего образования. Для подтверждения своих предположений мь провели интервью студентов из разных уголков Украины, изучающих иностранные языки. Mы опросили шесть респондентов из разных университетов Украины на эту тему: Харьковский национальный университет имени В. Н. Каразина, Горловский институт иностранных языков, Львовский национальный университет имени Ивана Франко, Киевский национальный лингвистический университет, Национальный технический университет «Харьковский политехнический институт» и Тернопольский национальный педагогический университет имени Владимира Гнатюка. Каждому респонденту дали имя (A-F), чтобы сохранить их анонимность. Мыл представили результаты интервью в этой статье. Студенты говорят, что проблемь не всегда зависят от вузов, а зачастую от личньх качеств студентов и преподавателей и современных тенденций на рынке труда. Мы дали несколько рекомендаций: учебную программу необходимо скорректировать в пользу основных предметов или даже предметов, которые сделают выпускников более подходящими для некоторых долюностей, чем людей без высшего образования; педагогический состав должен иметь специиальное педагогическое образование для повышения своего педагогического мастерства; университеты должны нанимать носителей преподаваемых языков; университетам необходимо разработать такие учебные программы, которые сделают их выпускников более привлекательными кандидатами на рынке труда. Главный вывод должен быть таким: система высшего образования должна идти в ногу со временем и меняться в зависимости 
ISSN Online: 2312-5829 Educological discourse, 2021, № 2 (33)

от рынка труда, убеждений студентов и современных тенденций в науке $u$ технологиях.

Ключевые слова: деактуализачия; иностранные языки, студенты; преподавател; украинская система образования; университетьл.

Стаття надійшла до редакиіï 23.02.2021 p. Прийнято до друку 09.06.2021 p. 